\title{
13
}

\section{Developing a Plan to Control Combined Sewer Floatables in Ottawa, ON}

\author{
Thomas L. Newman, Louis Julien and Gregory A. Clarke
}

Floatable pollution is an aesthetic nuisance often associated with runoff from urban areas and other sources. In 2008, the City of Ottawa, Ontario initiated a study of floatable pollution in an effort to develop a pollution prevention and control plan to control combined sewer floatables in compliance with applicable Ontario Ministry of the Environment (MOE) regulations. The floatables study, performed by G. A. Clark and Associates Limited and HydroQual, Inc., included field measurements and desktop analyses to define the nature of the combined sewer floatables issue in Ottawa, and to estimate floatables capture under existing conditions and with selected control alternatives.

The study recommended the implementation of several actions to cost effectively improve floatables control. Study recommendations included continuing existing activities that control street litter, implementing the real time control (RTC) program already underway to control combined sewer overflow (CSO) discharges, installing gas traps on all catchbasins in the study area, and conducting floatables monitoring and analyses for a period of three years to track the annual capture of floatables.

\subsection{The Floatables Problem}

Floatables discharged into receiving waters create a variety of problems. Visible floating material degrades the aesthetics of waterways and their shorelines, which in turn can contribute to loss of use (e.g. beach closings) and can have an adverse economic impact on recreation and business in an area. Debris slicks represent a potential hazard to commercial and recreational boating. Cases are

Newman, T., L. Julien and G.A. Clark. 2012. "Developing a Plan to Control Combined Sewer Floatables in Ottawa, ON." Journal of Water Management Modeling R245-13. doi: 10.14796/JWMM.R245-13.

(C) CHI 2012 www.chijournal.org ISSN: 2292-6062 (Formerly in On Modeling Urban Water Systems. ISBN: 978-0-9808853-7-8) 
frequently documented reporting death and injury to various forms of wildlife that ingest or become entangled in floatable debris. When the floatable material contains items of an unsanitary or sensitive nature, such as syringes, condoms or feminine napkins, the impacts on public health and aesthetics are intensified.

\subsubsection{Sources and Fate of Combined Sewer Floatables}

By the time floatables wash up along the shorelines, they have typically travelled a considerable distance. Studies performed in the city of New York (HydroQual, 1993) determined that about $95 \%$ of floatable litter items discharged from CSOs originated as street litter; the remaining 5\% originated as toilet litter (personal hygiene items, typically flushed down toilets).

A floatable item deposited on a street or sidewalk and not removed by street sweeping will likely be washed into a catchbasin during a rainfall event. If the item is not retained in the catchbasin and removed when the catchbasin is cleaned, the item will be flushed into the sewer system. If the item is not conveyed to the waste water treatment plant it will be discharged with CSO. Unless an end-of-pipe facility, such as a floatables containment boom, captures the item before it reaches the open water, prevailing currents or winds can transport it downstream or onshore.

Figure 13.1 represents various typical sources of floatable materials, the pathways these materials take through the combined sewer system (CSS) to the receiving water, and various points where floatables are typically intercepted for proper disposal (Newman, 1999).

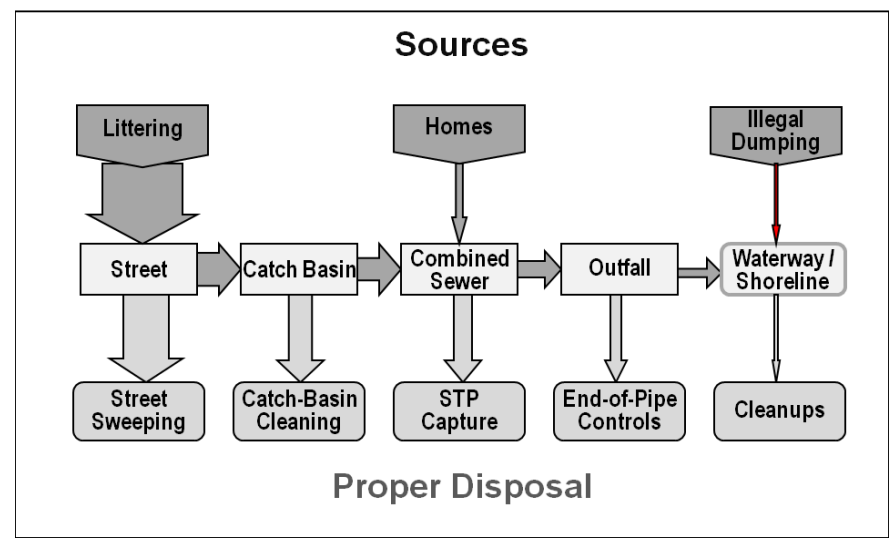

Figure 13.1 Sources and fate of CSO floatables.

Sources of street litter in combined sewers include deposition to streets and sidewalks and directly to catchbasins. Sources of toilet litter include sanitary 
sewage and, perhaps surprisingly, street litter, in which the occurrence of items such as condoms, tampon applicators, and syringes has been documented as perhaps $1 \%$ to $5 \%$ of all items (HydroQual, 1995). This floatables process train provides a conceptual framework to analyze and evaluate floatables conditions and the effectiveness of controls within a particular drainage system.

\subsubsection{Regulations}

Treatment requirements for municipal combined and partially separated sewer systems are contained in the Ontario MOE Procedure F-5-5, Determination of Treatment Requirements for Municipal and Private Combined and Partially Separated Sewer Systems, which is a supporting document for Guideline F-5, Levels of Treatment for Municipal and Private Sewage Treatment Works Discharging to Surface Waters. Through Procedure F-5-5, the MOE requires operators of CSSs to:

develop a pollution prevention and control plan;

meet minimum CSO control requirements; and

provide additional controls for CSO impaired beaches and as

otherwise required by receiving water conditions.

Control of CSO floatables is both explicitly and indirectly addressed in the procedure, but the procedure does not specify what receiving water conditions require floatables control, nor does it indicate a specific target level of combined sewer floatables control. The MOE's minimum CSO controls explicitly address floatables with the requirement of a floatables control program for "coarse solids and floatable materials, e.g. by reducing the amount of street litter that enters the catchbasins and the CSS; by removing debris from CSOs at the outfalls using measures such as trash racks and screens; and by removing floatables from the surface of the receiving water after a CSO occurs." In addition, the minimum CSO controls also include establishing pollution prevention programs to control sources; the MOE suggests programs such as "street cleaning to reduce CSO floatables" and "public education on anti-littering."

Control of CSO floatables is also indirectly addressed through other minimum CSO controls, particularly those requiring the reduction of CSO volume, such as the requirement to maximize CSO capture for treatment at the sewage treatment plant (STP) by maximizing collection system storage and by maximizing inflow rates at the STP. The minimum CSO controls prescribe a system wide CSO capture criterion of all dry weather flow plus $90 \%$ of the volume resulting from wet weather flow, applied for the seven month period commencing within fifteen days of April 1, and average meteorological conditions. Captured combined sewage is to receive a minimum of primary treatment, which includes removal of floatables. 


\subsubsection{Defining the Nature of Floatables}

Though Procedure F-5-5 targets "coarse solids and floatables" as the subject of the required floatables control program, the term floatables is not explicitly defined. CSO discharges contain a wide array of materials in various forms that can be classified in a number of ways, and the effectiveness of different methods of control can depend on the characteristics of the materials. Therefore, it is important that the nature of floatables be well understood when investigating control alternatives.

The term floatable materials would appear to refer to any positively buoyant substance. However, in most contexts, floatables refers to both positively and near-neutrally buoyant items. Even items that tend to sink in quiescent conditions can be carried as floatables in CSO discharges to the receiving water and become floatables washups on shorelines. Some materials, such as porous paper, lose buoyancy over time as they absorb water.

Furthermore, floatables typically refers to solid items rather than liquids or colloids. Separate regulatory criteria are typically applicable to floatable liquids or semi-solids, such as oil and grease. Similarly, floatables are also generally considered to be larger solids, rather than the smaller, suspended or settleable solids typically associated with the buildup of sediment mounds in receiving waters.

Floatables represent a visual pollution, and hence have a detection limit related to their size. Though Procedure F-5-5 does not provide guidance on size, some regulatory agencies, such as the United States Environmental Protection Agency (USEPA), target visible solids and floatable materials, while other regulatory agencies designate a minimum size. For example, the state of New Jersey targets solids larger than $0.5 \mathrm{in} .(13 \mathrm{~mm})$ for removal.

Although material discharged from CSOs includes a significant amount of natural materials, such as leaves, twigs and other vegetation, these materials are not typically considered floatable pollution because they are not objectionable when found on beaches. In fact, beach cleanup projects typically do not include these natural materials when they collect and characterize washup materials. While large quantities of such materials can accumulate and cause a nuisance in smaller enclosed receiving waters, studies have shown that this matter typically does not contribute significantly to the total stormwater nutrient load with respect to nitrogen and phosphorus (Allison, 1998). As these natural materials are essentially non polluting, they are not considered to be floatable pollution; however, the amount of natural materials discharged can be significant, and the collection and handling of this matter must be considered when certain control alternatives are selected. 
This chapter refers to floatables as follows:

- Floatables are visible items of anthropogenic origin which are buoyant or semi-buoyant in that they will float on or near the surface of the receiving water to the extent that they can be transported to downstream waters and shorelines. Liquids and colloidal material are not included in this definition.

- CSO floatables refers to floatables that are typically present in combined sewage. These items consist of street litter and toilet litter.

\subsubsection{Control of Floatables}

Source controls include measures that reduce littering, such as public education and outreach campaigns to stop littering, programs to increase the number of available litter baskets, or programs to enhance street cleaning. Source controls can also include measures to prevent items from passing from catchbasins into the CSS, such as closing open curb inlets or installing catchbasin gas traps. Inputs of toilet litter to the sewer system may also be targeted in public outreach programs.

Best management practices such as the maximization of collection system storage and the maximization of flow to the STP can increase the capture of floatables along with the captured volume of combined sewage. However, in some cases the control of floatables differs from the control of combined sewage volume. For example, implementation of inflatable dams to increase collection system storage may result in floatables capture, but only to the extent to which an entire wet weather event is captured completely; despite the increased volume capture, all buoyant floatables retained behind the dam could discharge if water elevations top the crest of the inflatable dam for even a brief period of time. Inline baffles placed at or upstream of CSS regulators can be used in conjunction with weirs or inflatable dams to retain buoyant floatables. Other inline options include in-regulator mechanical screens, and vortex devices as regulators, and stilling vaults.

Control of floatables downstream of regulators can involve CSO netting or screening, and end-of-pipe booming and skimming. Once floatables have been released to a waterbody, control options include open water skimming as well as beach cleanups.

\subsection{Characterizing Existing Floatables Conditions}

A primary goal of this study is to characterize the existing condition with respect to CSO floatables. This characterization is accomplished through the 
compilation of existing information, limited field sampling, and the application of relationships and modeling concepts, described further in Section 13.3.

This section presents a summary of the existing information relating to Ottawa's floatables for each of the elements shown in the floatables process train (Figure 13.1 above), starting with the sources of floatables and working downstream through the CSS to the receiving water bodies and beaches where floatables control is ultimately sought.

\subsubsection{Street Litter}

Studies in New York City (HydroQual, 1993; 2005) and other municipalities (SAIC, 1987; CDM 1996) have shown that the great majority of CSO floatables originated as street litter that was flushed into the CSS during wet weather. Street litter in both separately sewered and combined sewer areas can contribute to floatables discharges to the receiving water. Separating sewers can actually increase the discharge of street litter to the receiving water if no end-of-pipe controls are implemented, because none of the stormwater runoff is diverted to the STP for treatment.

\section{Factors Generally Influencing Street Litter Levels}

Major sources of street litter are pedestrians and motorists. As a general rule, littering is proportional to the population density, not only of residents, but also of the transient population (e.g. commuters and tourists). The tendency of the public to litter is presumably based not only on the level of environmental awareness and caring, but also on the type of activity (for example, festivals or fast food outlets in commercial areas are associated with increased waste materials, while residential areas tend to have less waste material) and the level of inconvenience to dispose of litter properly (e.g. the availability of litter receptacles). Enforcement of anti-littering laws can also have an impact.

Municipal operations also influence street litter levels. Insufficient numbers of litter receptacles and insufficient wastebasket cleaning contribute to higher litter levels. Garbage pickup operations can also contribute to increased street litter levels. Street cleaning operations reduce litter levels. Litter ordinances making property owners responsible for clearing litter can reduce street litter. Public-private partnerships such as "adopt a street" can also control litter levels.

In some cases, commercial or industrial activity can represent a source of street litter that is independent of pedestrians. For example, retail businesses can generate packaging waste that, if not properly handled, can be a source of street litter.

Finally, meteorological conditions also influence street litter levels. Litter on the street can be removed by wind and rain. Whereas wind generally moves 
litter onto adjacent properties, rain generally moves street litter along the gutters and into catchbasins. Heavier rainfall intensities generally cause wider and faster gutter flows that can carry greater amounts of litter to the catchbasins. Larger litter items will remain on the street if they cannot pass into the catchbasins via storm grates or open curb inlets; open curb inlets provide the greatest opportunity for litter to be flushed from the streets into the catchbasins.

\section{Monitoring Street Litter, Summer 2008}

In order to characterize street litter levels in Ottawa, a limited survey program was conducted during the summer of 2008. The purpose of the street litter survey program was to assess the extent to which there is geographical variation in street litter levels within the city, to determine whether street litter levels may be correlated with land use, and to provide a baseline to assess future trends and the impacts of factors such as weather and enhanced source controls.

The street litter monitoring was performed using a scorecard procedure that has been in use in New York City for nearly 40 y (NYC, 2010). This procedure assigns a numerical scorecard litter rating (SLR) on a seven point scale, with the best rating (1.0) assigned when there is absolutely no litter visible, and the worst rating (3.0) assigned where litter is heavy and continuous along the curb. Monitoring involved assigning SLRs to one side of the street, typically consisting of four SLRs assigned along a single block. Monitoring was performed at predetermined locations by a passenger in an automobile, with SLRs being entered directly into a laptop computer.

HydroQual previously developed information to enable the SLRs to be expressed in terms of the average number of litter items per unit length of curb, or litter concentration. Because the relationship between SLR and litter concentration is independent of location, it can be applied to the results of the Ottawa surveys to develop a relative measure of the quantity of street litter available to enter the CSS.

Street litter levels were monitored at a total of 120 blockfaces selected to provide a representative sampling of geographic areas within the city's downtown combined sewer drainage area, as well as for specific land use types within that area.

Each location was monitored on three different occasions at intervals of approximately two weeks to ensure that monitored conditions included the impact of factors such as rainfall and street cleaning. To minimize the influence of factors such as day of week and time of day, each survey was performed during the middle of the week and in the post rush hour period while daylight was sufficient to clearly view conditions.

The 2008 monitoring period included several rainfall events with daily total rainfalls of at least $30 \mathrm{~mm}$, and at least one event with relatively high rainfall 
intensities ( $5 \mathrm{~min}$ peak intensity of $30 \mathrm{~mm} / \mathrm{h}$ to $70 \mathrm{~mm} / \mathrm{h}$ ). As a result, the street litter monitoring reflects conditions that are associated with rainfall activity as well as ongoing street cleaning operations.

\section{Results of Street Litter Ratings}

The results of the street litter monitoring were compiled and assessed overall and with respect to geographic location and land use. Overall, most streets were observed to be very clean, with $98 \%$ of all street-averaged surveys having an SLR of less than 1.5-the threshold that public surveys in New York City considered acceptably clean.

To assess how SLRs varied geographically across the city's combined sewer drainage areas the average SLR at each location was posted into a geographical information system (GIS) format and interpolated using standard inverse distance weighting techniques to reveal general geographical patterns.

SLRs were also assessed in the context of land use. Low density residential areas had the highest percentage (about 65\%) of no litter observations $(\mathrm{SLR}=1.0)$ along those streets, while commercial areas had the lowest percentage (about $30 \%$ ) of no litter ratings, with high density residential areas not far behind. High density residential and commercial had the highest percentage of observations with the poorest litter ratings $(\mathrm{SLR}=1.5$ and 1.8) along those streets.

\section{Application of SLR Results in Floatables Analysis}

As mentioned previously, HydroQual developed relationships enabling SLRs to be expressed in terms of item counts per unit length of curb. These relationships, based on two years of item counts along streets that received SLRs, enable the SLR scores to be converted into a quantity of litter items for a given street or area characterized with a certain SLR.

Although the street litter monitoring did not rate every street in the Ottawa combined sewer area, an estimate of the quantity of litter on streets was made through application of the SLR distribution as related to land use types. Because land use information is available city wide, application of the SLR distributions described above provided the basis for calculation of the litter levels for each individual combined sewer subsystem in the study area.

The results of these calculations are summarized in Table 13.1. As shown in Table 13.1, the Kent Street Trunk and Cathcart/King Edward subsystems have the highest calculated litter concentrations overall. These litter levels average approximately $40 \%$ more litter on streets than the Hemlock subsystem, which had the lowest calculated litter concentrations. 
Table 13.1 Land use and calculated street litter concentrations.

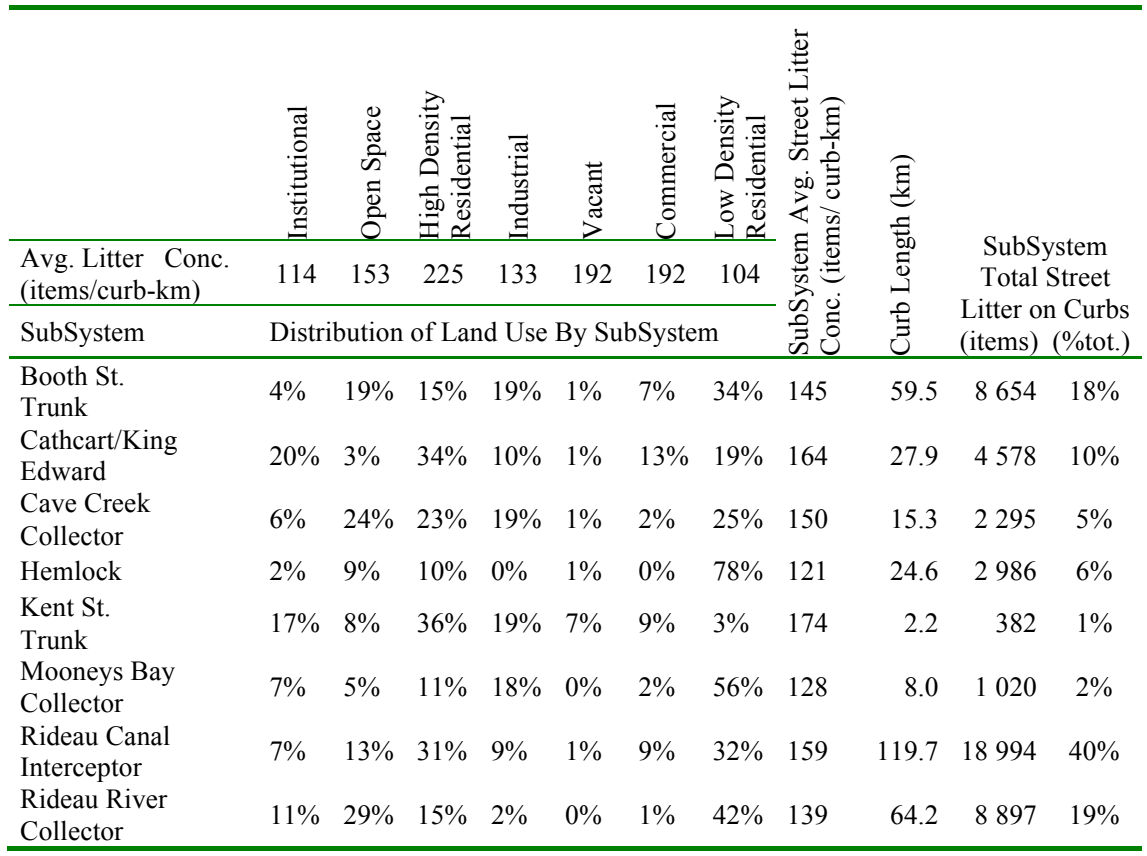

Based on the above analysis and the total length of streets in the combined sewer portion of each subsystem, the quantity of litter on streets was calculated for each subsystem. As shown, the Rideau Canal Interceptor subsystem represents about $40 \%$ of the total street litter generated in the combined sewer study area. The Rideau River Collector and Booth Street Trunk subsystems each represent about 19\%, and the Cathcart/King Edward subsystem represents about $10 \%$. The remaining subsystems total about $14 \%$ of the study area total.

\subsubsection{Catchbasins}

Catchbasins provide an entry to the city's combined and storm sewer systems for surface runoff which may carry street litter containing floatables along with it, allowing them to enter the sewers. Certain catchbasin features can be effective in preventing floatables from entering the sewer system while at the same time allowing the runoff to enter, so preventing flooding of the catchbasin.

\section{Factors Influencing Catchbasin Retention of Floatable Litter}

Studies performed for the City of New York (HydroQual, 1995) have shown that the most important catchbasin feature affecting floatables control is the 
presence of a gas trap, though inlet type and sump depth are also relevant. Each of these features is described below. These studies showed that catchbasin cleaning does not enhance floatables control in catchbasins, since floatables retention in catchbasins increases with the amount of debris in the catchbasin (i.e. material in the catchbasin forms a filter that allows less and less debris to pass through, until it ultimately clogs). The studies also determined that the need for catchbasin cleaning was a function of the accumulation of grit, rather than of litter.

Runoff enters catchbasins through either a vertical cut in the curb or through a horizontal grate. Both designs are used in Ottawa, although newer designs favor the vertical curb cut, which tends to have lower maintenance requirements and is also bicycle friendly. Catchbasins with the open, vertical curb cut design can reduce the risk of street flooding caused by obstruction of the inlet with mats of material. However, the vertical cut curb inlet has an opening that is large enough to allow cans, bottles, and other debris to pass freely into the catchbasin. Some vertical cut curb inlets have vertical or horizontal bars, which prevent some of the larger items from entering the catchbasin.

Other catchbasin designs feature horizontal grates with openings of various shapes and sizes that generally prevent items as large as cans or bottles from passing through. Grates with parallel, relatively widely spaced bars represent a safety hazard to bicycle tires. Bicycle-safe grates with smaller openings or cross-hatch designs prevent bicycle tires from catching in the grate; the smaller openings presumably prevent a greater proportion of street litter items from entering the basins. However, the City of Ottawa has found that horizontal grates tend to require higher maintenance of the road bed than the vertical cut curb inlet designs, probably due to frost-heave issues.

Some catchbasins are equipped with sumps that trap material that would otherwise discharge into the sewer. The sump is formed by a vertical offset between the catchbasin invert and the invert of the exit pipe. These sumps provide storage for grit, sediments, and trash until the catchbasin is cleaned. Catchbasins connected to combined sewers are often equipped with gas traps to prevent sewer gases from venting up to street level.

Typical gas trap designs require a catchbasin with a sump to provide a depth of standing water in the bottom of the catchbasin. The gas trap itself is essentially an elbow extending up from the standing water and then out into the catchbasin outlet pipe. Successful gas trap designs prevent sewer gas venting without adversely obstructing flows or becoming clogged with debris.

Studies in New York City (HydroQual, 1995) indicate that catchbasins equipped with gas traps retain an average of $76 \%$ of the street litter that enters the catchbasin, compared to similar catchbasins without gas traps, which retain an average of $10 \%$ of the street litter that enters. 


\section{Available Information Regarding Catchbasins in Ottawa}

According to information provided by the city, there are roughly 3620 storm inlets (catchbasins) along the $113 \mathrm{~km}$ of streets comprising Ottawa's ultimate combined sewer area. Assuming that the concentration of catchbasins is similar throughout the study area, then there are about 5150 catchbasins along the $161 \mathrm{~km}$ of streets of the study area.

Several different catchbasin designs are currently in use in Ottawa. One group of designs features curb inlets, and a second group features one of several grate designs instead of a curb inlet. Limited information was available regarding the relative prevalence of these various catchbasin designs.

Various gas trap designs are also in use throughout the city. An older design resembles a box with a top that tapers up toward the catchbasin wall with the exit pipe, with a $150 \mathrm{~mm}$ hole at the bottom. The current standard gas trap features a slimmer ( $330 \mathrm{~mm}$ wide, $100 \mathrm{~mm}$ deep and $600 \mathrm{~mm}$ tall) box that is open at the bottom. Vortex valves, which are designed to regulate flow leaving catchbasins, also function as gas traps.

Catchbasin Survey, Summer 2008

In order to estimate the relative dominance of certain catchbasin types and characteristics in the combined sewer areas of the city, a survey of catchbasins was conducted on September 2, 2008. The catchbasin survey involved inspection of 51 streets located throughout the downtown area. The results of the survey are presented in Table 13.2.

Table 13.2 Catchbasin survey results, 2008.

\begin{tabular}{lllllll}
\hline SubSystem & $\begin{array}{l}\text { Number of } \\
\text { Street } \\
\text { Blockfaces } \\
\text { Inspected }\end{array}$ & $\begin{array}{l}\text { Number of } \\
\text { Catchbasins }\end{array}$ & $\begin{array}{l}\text { Percent } \\
\text { with } \\
\text { Open } \\
\text { Curb } \\
\text { Inlets }\end{array}$ & $\begin{array}{l}\text { Number } \\
\text { Inspected } \\
\text { for Gas } \\
\text { Trap }\end{array}$ & $\begin{array}{l}\text { Number } \\
\text { Found } \\
\text { with } \\
\text { Gas } \\
\text { Trap }\end{array}$ & $\begin{array}{l}\text { Percent } \\
\text { with } \\
\text { Gas } \\
\text { Trap }\end{array}$ \\
\hline $\begin{array}{l}\text { Booth Street } \\
\text { Trunk }\end{array}$ & 6 & 100 & $45 \%$ & 17 & 11 & $65 \%$ \\
$\begin{array}{l}\text { Cathcart/King } \\
\text { Edward }\end{array}$ & 5 & 98 & $7 \%$ & 11 & 1 & $9 \%$ \\
$\begin{array}{l}\text { Cave Creek } \\
\text { Collector }\end{array}$ & 2 & 20 & $50 \%$ & 2 & 0 & $0 \%$ \\
$\begin{array}{l}\text { Kent Street } \\
\text { Sewer }\end{array}$ & 3 & 45 & $4 \%$ & 4 & 0 & $0 \%$ \\
$\begin{array}{l}\text { Mooney's Bay } \\
\text { Collector }\end{array}$ & 7 & 75 & $25 \%$ & 7 & 0 & $0 \%$ \\
$\begin{array}{l}\text { Rideau Canal } \\
\text { Interceptor }\end{array}$ & 20 & 333 & $22 \%$ & 38 & 18 & $47 \%$ \\
$\begin{array}{l}\text { Rideau River } \\
\text { Collector }\end{array}$ & 8 & 152 & $16 \%$ & 19 & 0 & $0 \%$ \\
Overall & $\mathbf{5 1}$ & $\mathbf{8 2 3}$ & $\mathbf{2 2 \%}$ & $\mathbf{9 8}$ & $\mathbf{3 0}$ & $\mathbf{3 1 \%}$ \\
\hline
\end{tabular}


The survey methodology involved recording the total number of catchbasins found on each street, with each classified according to one of five design types. In addition, a more detailed inspection of at least one catchbasin on each street was performed to assess whether a gas trap was present. In some cases, additional catchbasins on the same street were also inspected for gas traps.

A total of 823 catchbasins were found on the 51 streets surveyed. Overall, $22 \%$ of the catchbasins had open curb inlets. On a combined sewer subsystem basis, the percentage of catchbasins with open curb inlets varied from less than about 5\% in the Kent Street Trunk and Cathcart/King Edward areas, to about $50 \%$ in the Cave Creek Collector and Booth Street Trunk areas. Of the 98 catchbasins inspected for gas traps, 31\% had a gas trap. The percentage of catchbasins with gas traps varied by subsystem from zero up to $65 \%$.

\section{Application of Catchbasin Information in Floatables Analysis}

The primary factor in determining the percentage of street litter that can pass into the sewer system is the percentage of catchbasins in each combined sewer subsystem that are equipped with gas traps. The analysis conducted herein used the subsystem specific percentages shown in Table 13.2 above except for subsystems where fewer than 10 catchbasins were checked for traps; in those cases, the overall average percentage (31\%) was used instead.

\subsubsection{Combined Sewer Systems}

The combined sewer system (CSS) is the conduit which conveys floatables (from both street litter and toilet litter) either to the sewage treatment plant (STP) or, when wet weather flows of combined sewage exceed the system capacity, to combined sewer outfalls (CSOs). The ability of the CSS to capture floatables for treatment at the STP is an important factor in the floatables process train. The capture of floatables may or may not be similar to the capture of flow depending upon how excess combined sewage is diverted to the outfall

\section{Factors Influencing Floatables Capture at Regulators}

Combined sewer systems allow for flows exceeding the capacity of the system to discharge to an outfall. In an average rainfall year, a certain percentage of the annual volume of wet weather flow is captured and treated at the STP. If floatables are completely mixed in the combined sewage flow, and floatables concentrations are relatively constant during wet weather events, the capture percentage of floatables will likely equal that of wet weather flow.

Some situations can cause the capture of floatables to differ from that of wet weather flow. First flush effects, if applicable to floatables, could impact the relationship between floatables capture and volume capture. If most floatables are flushed into the combined sewer at the onset of a wet weather event, and the 
sewer system has the capacity to accept that flow, then a greater percentage of floatables will be captured than indicated by the overall volume capture. In this instance, the distribution of floatables in time could favor their capture.

In addition, certain regulator configurations and operational situations can also influence the capture of floatables throughout overflow periods. For instance, regulators that divert flow from the trunk sewer to the interceptor via a cut along the floor of the trunk sewer may capture a lower proportion of floatables than flow volume if floatables have an opportunity to rise toward the water surface in the regulator or in the approach sewer. In this instance, the distribution of floatables in space will tend to favor their discharge from the regulator.

First flush effects and the impact of regulator configurations on floatables mixing in sewers and regulator structures are likely to be site specific and highly variable over time. Analysis of these issues would require site specific testing. Therefore, this study takes an approach whereby analyses are based upon the completely mixed assumption, and the sensitivity of the results is assessed by using a reasonable estimate of the potential degree to which floatables may not be well mixed. If the results are sensitive to this issue, some testing or observations should be performed in the future to verify whether there is a first flush effect (i.e. floatables are not completely mixed in time) and whether floatables capture equals volumetric capture (i.e. floatables are completely mixed in space).

\section{Combined Sewage Volume Capture in Ottawa}

Estimates of the existing wet weather flow capture rate were based on results of sewer system modeling as reported in Ottawa's Regulator Upgrades PreDesign Report (August 10, 2006). Modeling performed for baseline conditions and the 1980 rainfall year were used to characterize wet weather flow capture for the existing infrastructure and operation in an average rainfall year. Results of the modeling are summarized for each combined sewer subsystem in Table 13.3 .

Table 13.3 Volume capture at regulators, by subsystem.

\begin{tabular}{lc}
\hline \multicolumn{1}{c}{ Subsystem } & $\begin{array}{c}\text { Annual Volume Capture } \\
\text { (\% Wet Weather Flow Volume) }\end{array}$ \\
\hline Booth Street Trunk & 72 \\
Cathcart/King Edward & 89 \\
Cave Creek Collector & 93 \\
Hemlock & 70 \\
Kent Street Trunk & 88 \\
Mooney's Bay Collector & 99 \\
Rideau Canal Interceptor & 28 \\
Rideau River Collector & 94 \\
\hline Source: Regulator Upgrades Pre-Design Report, August 10, 2006
\end{tabular}

Source: Regulator Upgrades Pre-Design Report, August 10, 2006 
The modeling results indicate that in an average year as many as $38 \mathrm{CSO}$ events occur in the Rideau Canal Interceptor area, where volume capture of $28 \%$ is the lowest among the combined sewer subsystems.

\section{Applicability of Volume Capture for Floatables Capture}

This study performs one set of calculations assuming that the floatables capture is equivalent to the volume capture, and another set of calculations to determine the extent to which the results might be different, given a different floatables capture rate based on the available information.

If floatables tend to concentrate at the beginning of the storm in a first flush effect, and this portion of the storm is captured, then floatables capture at the regulators may be higher than the overall volume capture. No information is available concerning how the concentration of floatables changes in combined sewage during the course of a wet weather event. However, an analysis of the hydraulic model results could be performed to determine how long after the onset of wet weather flow the regulator captures all the inflow. If this period is reasonably long (e.g. $\geq 1 \mathrm{~h}$ ) or represents a reasonably large rainfall (e.g. $\geq 10$ $\mathrm{mm}$ ), then if an initial concentration of floatables does occur, it is possible that the capture of floatables could be significantly higher than the overall volume capture. On the other hand, if floatables concentrations in combined sewage are related more to rainfall intensity or flow rates (i.e. higher rainfall intensity moves disproportionately more floatables), then the capture of floatables at regulators may be lower than the overall volume capture at the regulator.

If floatables are not well mixed spatially in regulators during overflow periods, floatables capture at the regulators may be higher or lower than the overall volume capture, depending upon the regulator configuration. Drawings of the regulators and trunk sewers upstream of the regulators were reviewed to assess whether geometric concerns might affect the applicability of the completely mixed assumption. All else being equal, turbulence will favor mixing, so major junctions, bends in the trunk sewer, and abrupt changes in flow direction at the regulator increase mixing at those locations. Long straight trunk sewers with large diameters and regulators with large chambers that allow flow velocities to slow will tend to favor floatables separation (i.e. floatables rising to the surface of the water) over mixing.

Most regulators in the study area (including the Rideau Canal Interceptor regulator) feature floor cuts through which flows are diverted to the interceptor for treatment. In wet weather, it is unclear how much turbulent mixing occurs in the upstream trunks and at the regulator. However, it is evident that as flows and water surface elevations increase during wet weather, floatables near the water surface will tend to pass over the floor cuts and discharge with CSO. 
An analysis of the Rideau Canal Interceptor regulator indicates that, given the long $(>150 \mathrm{~m})$ straight run of the $2 \mathrm{~m} \times 2.3 \mathrm{~m}$ approach sewer and the floor cut geometry of the regulator, it would not be unreasonable if the floatables capture rate were half of the annual volume capture. Therefore, the half volume capture assumption was identified as a reasonable lower bound for floatables capture for Ottawa's regulators.

\section{Percentage of Toilet Litter in CSO Floatables}

Although the prevalence of toilet litter items, such as tampon applicators, condoms and syringes, is typically low relative to that of street litter items, public sensitivity to toilet litter items may be much higher than to street litter items, particularly in cases where there is recreational contact with the receiving water. The prevalence of toilet litter items in CSO floatables is presumably proportional to the fraction of sanitary sewage in the CSO discharge, a parameter sometimes tracked in sewer system modeling. Sorting of floatables captured in the CSO discharge provides a direct measurement.

To provide an estimate of the fraction of toilet items in Ottawa CSO, a floatables boom was installed across the tailrace to capture floatables discharged from the Booth Street Trunk, Mooney's Bay Collector and Cave Creek Collector subsystems. Floatables captured during two different storms were sorted and characterized by item type. These results were consistent with results of previous sampling analyses performed in New York City and other jurisdictions, which indicate that from about $1 \%$ to $10 \%$ of CSO floatable items can be characterized as toilet litter.

\section{Application of Combined Sewage Capture in Floatables Analysis}

The analysis of existing floatables capture at the regulators utilizes the wet weather volume capture estimates shown in Table 13.3 above to determine the fraction of combined sewer floatables that are diverted to the STP for treatment. The analysis also assumes that combined sewer floatables in all locations consist of 5\% toilet litter. Sensitivity analyses determined that the percentage of toilet litter did not significantly affect the results, but that the well mixed assumption did. Therefore, the analysis includes additional calculations in which the floatables capture rate at the regulators is assigned as half the volume capture rate (as determined for the RCI regulator).

\subsubsection{CSO Outfalls}

In some cases, floatables controls can be implemented at or near CSO outfalls. Potential end-of-pipe controls include end-of-pipe netting and boom-and-skim operations. In Ottawa, most discharges from the combined sewer system are via submerged outfalls. The exceptions include the outfall at the tailrace (discharg- 
ing from the Booth Street Trunk, Cave Creek Collector, and Mooney's Bay Collector systems) and the John Street outfall (discharging from the Rideau River Collector system). Although there have been observations of floatables collecting on the water surface in venting structures for the submerged outfalls, these structures do not appear to have the capacity to retain significant quantities of material, and cleaning of these structures has not been performed.

Because there are no end-of-pipe floatables controls installed at this time on any of the city's outfalls, the floatables modeling analysis will not apply floatables controls at the CSO outfalls for the existing condition.

\subsubsection{Receiving Waters and Shoreline Areas}

The goal of floatables control is to improve aesthetics associated with the receiving waters, shorelines, and beaches. As indicated in Figure 13.1, CSOs represent one possible source of floatables to these end points. In riverine systems, floatables can also be transported from upstream sources for long distances. Street litter can be discharged through storm sewers, and direct deposition of floatables to the waterbody can also occur from illegal dumping from the shoreline or from watercraft. Floatables along shorelines and beaches may also be deposited by direct littering. Analysis of floatables found on streets and sidewalks, in CSO and stormwater discharges, and in open water trawls indicates that certain types of materials, such as porous paper and cigarette butts, absorb water and either sink or disintegrate after short periods of time (HydroQual, 1995). As a result, occurrences of these materials on beaches or on shorelines are unlikely to have originated from CSO discharges.

\section{The Ottawa River and Tributaries}

Ottawa's combined sewers discharge to the Ottawa River. Although the Rideau Canal and the Rideau River also flow through the city, only two small CSOs discharge into those water bodies. However, the Rideau Canal and Rideau River both receive stormwater inputs draining portions of the urban area. In addition, littering during the skating season may also represent a significant source of floatables to the Rideau Canal during the spring thaw, although Parks Canada does conduct annual springtime cleanups. Finally, the Rideau Canal, the Rideau River and the Ottawa River may also contain floatables from upstream sources. Gatineau (population 240 000), located directly across the Ottawa River from Ottawa, also represents a potential source of floatables to that water body. In addition, the Gatineau River may introduce floatables into the Ottawa River at its confluence slightly downstream of the confluence of the Rideau and Ottawa Rivers. Recreational boating activities along the Rideau Canal and the Ottawa River are also potential sources of floatables. 
The shoreline of the Ottawa River is scenic and features recreational pathways, as well as several bridges with pedestrian access. Government buildings, including federal buildings, the Prime Minister's residence and foreign embassies, are also located along the Ottawa River, heightening the sensitivity of the area. In addition, there is a bathing beach on Petrie Island, about $20 \mathrm{~km}$ downstream of downtown Ottawa.

Shoreline Floatables Survey, Summer 2008

As part of this study, a floatables survey was conducted for the city's shorelines. A total of 13 sites were selected in either high profile or strategic locations of importance to tracking floatables (i.e. at upstream sites). Figure 13.2 shows the locations and results of the shoreline surveys.

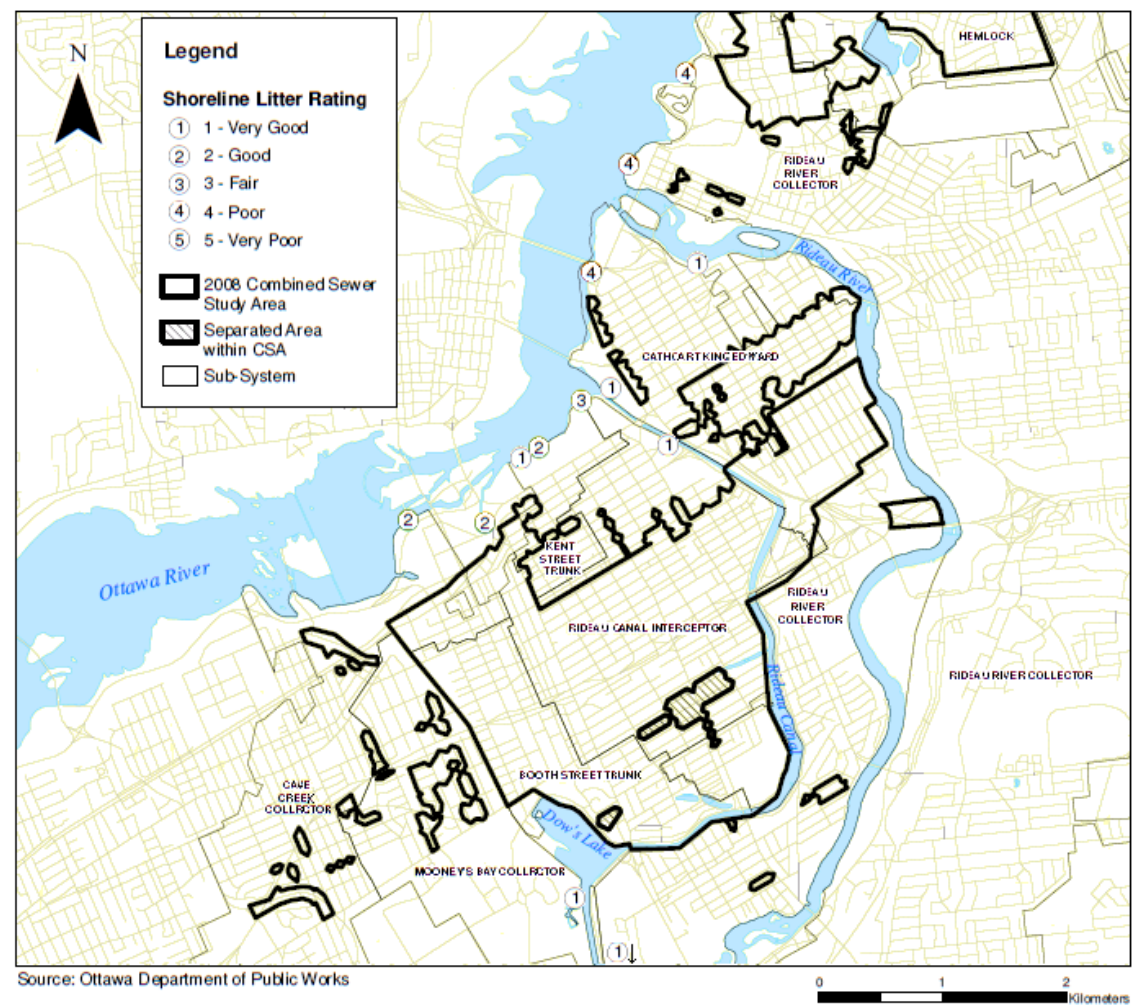

Figure 13.2 Shoreline survey locations and results.

The survey methodology, based on a procedure developed for use in New York City to track floatables conditions over time, involves a visual rating 
system similar to the street litter rating system described previously. Ratings relate the quality of the location on a 5 point scale, from Very Good (no floatables) to Very Poor (many floatables). At each selected location, a separate rating is given to the shoreline (a $50 \mathrm{ft}, 15.24 \mathrm{~m}$, square area from the waterline inland), to the near shore area (a $50 \mathrm{ft}, 15.24 \mathrm{~m}$, square from the waterline and away from shore), and to the off shore area (a $50 \mathrm{ft}, 15.24 \mathrm{~m}$, square from the outer edge of the near shore area toward the middle of the water body). Photographs are also taken. Because visual evidence of floatables can be sporadic, this type of visual record is useful in establishing longer term trends and characterizing the relative level of floatables in different areas.

The results of the surveys showed that all off shore ratings were very good and all near shore ratings were very good or good. The shoreline ratings showed the greatest variation from location to location, with more degraded conditions moving downstream along the Ottawa River.

\subsection{Modeling Analysis of Floatables Control, Existing Conditions}

The information discussed in the preceding sections was compiled and utilized within an analytical modeling framework to evaluate the overall sources and fate of floatables in the existing CSS. This floatables model provides an estimate of the overall control of CSO floatables for the city and the relative discharges of floatables from the individual combined sewer subsystems. It also provides a means to assess the impacts of implementing certain controls in various areas of Ottawa. Tables 13.4 and 13.5 summarize the floatables model inputs and outputs, respectively.

Table 13.4 Floatables model inputs, existing conditions.

\begin{tabular}{|c|c|c|c|c|c|c|c|}
\hline SubSystem & $\begin{array}{l}\text { Av. Street } \\
\text { Litter } \\
\text { Concen- } \\
\text { tration } \\
\text { (items/ } \\
\text { curb-km) }\end{array}$ & $\begin{array}{c}\text { Curb } \\
\text { Length } \\
(\mathrm{km})\end{array}$ & $\begin{array}{c}\text { Catch- } \\
\text { basins } \\
\text { with Gas } \\
\text { Traps (\%) }\end{array}$ & $\begin{array}{c}\text { Street } \\
\text { Litter } \\
\text { Retained } \\
\text { by Catch- } \\
\text { basins } \\
(\%)\end{array}$ & $\begin{array}{c}\text { CSS } \\
\text { Litter that } \\
\text { is Toilet } \\
\text { Litter }(\%)\end{array}$ & $\begin{array}{c}\text { Volume } \\
\text { Capture } \\
\text { of WWF } \\
(\%)\end{array}$ & $\begin{array}{c}\text { Capture } \\
\text { by End- } \\
\text { Of-Pipe } \\
\text { Controls } \\
(\%)\end{array}$ \\
\hline Booth Street Trunk & 145 & 59.5 & 65 & 53 & 5 & 72 & 0 \\
\hline Cathcart/King Edward & 164 & 27.9 & 9 & 16 & 5 & 89 & 0 \\
\hline Cave Creek Collector & 150 & 15.3 & 31 & 30 & 5 & 93 & 0 \\
\hline Hemlock & 121 & 24.6 & 31 & 30 & 5 & 70 & 0 \\
\hline Kent Street Trunk & 174 & 2.2 & 31 & 30 & 5 & 88 & 0 \\
\hline Mooney's Bay Col. & 128 & 8.0 & 31 & 30 & 5 & 99 & 0 \\
\hline Rideau Canal Int. & 159 & 119.7 & 47 & 41 & 5 & 28 & 0 \\
\hline Rideau River Col. & 139 & 64.2 & 0 & 10 & 5 & 94 & 0 \\
\hline
\end{tabular}


Table 13.5 Floatables model results, existing conditions.

\begin{tabular}{|c|c|c|c|c|c|c|c|c|c|}
\hline \multirow[b]{2}{*}{ SubSystem } & \multicolumn{2}{|c|}{$\begin{array}{c}\text { Average Quantity } \\
\text { of Street Litter } \\
\text { Available }\end{array}$} & \multirow{2}{*}{$\begin{array}{l}\text { Street } \\
\text { Litter to } \\
\text { CSS } \\
\text { (units) }\end{array}$} & \multirow{2}{*}{$\begin{array}{l}\text { Toilet } \\
\text { Litter to } \\
\text { CSS } \\
\text { (units) }\end{array}$} & \multirow{2}{*}{$\begin{array}{l}\text { Total } \\
\text { Litter to } \\
\text { CSS } \\
\text { (units) }\end{array}$} & \multirow{2}{*}{$\begin{array}{c}\text { Total } \\
\text { Litter to } \\
\text { CSO } \\
\text { (units) }\end{array}$} & \multicolumn{2}{|c|}{$\begin{array}{c}\text { Total Litter to } \\
\text { Receiving } \\
\text { Water } \\
\end{array}$} & \multirow{2}{*}{$\begin{array}{c}\text { Overall } \\
\text { Float- } \\
\text { ables } \\
\text { Capture } \\
(\%)\end{array}$} \\
\hline & (items) & $(\%)^{\mathrm{a}}$ & & & & & (units) & $(\%)^{\mathrm{a}}$ & \\
\hline $\begin{array}{l}\text { Booth St. } \\
\text { Trunk }\end{array}$ & 8654 & 18 & 4093 & 215 & 4308 & 1225 & 1225 & 11 & 86 \\
\hline $\begin{array}{l}\text { Cathcart/ } \\
\text { King Edward }\end{array}$ & 4578 & 10 & 3845 & 202 & 4048 & 450 & 450 & 4 & 91 \\
\hline $\begin{array}{l}\text { Cave Creek } \\
\text { Collector }\end{array}$ & 2295 & 5 & 1596 & 84 & 1680 & 115 & 115 & 1 & 95 \\
\hline Hemlock & 2986 & 6 & 2076 & 109 & 2186 & 654 & 654 & 6 & 79 \\
\hline $\begin{array}{l}\text { Kent St. } \\
\text { Trunk }\end{array}$ & 382 & 1 & 266 & 14 & 279 & 33 & 33 & $<1$ & 92 \\
\hline $\begin{array}{l}\text { Mooney's Bay } \\
\text { Collector }\end{array}$ & 1020 & 2 & 709 & 37 & 747 & 10 & 10 & $<1$ & 99 \\
\hline $\begin{array}{l}\text { Rideau Canal } \\
\text { Interceptor }\end{array}$ & 18994 & 40 & 11156 & 587 & 11744 & 8412 & 8412 & 74 & 57 \\
\hline $\begin{array}{l}\text { Rideau River } \\
\text { Collector }\end{array}$ & 8897 & 19 & 8008 & 421 & 8429 & 529 & 529 & 5 & 94 \\
\hline $\begin{array}{l}\text { Study Area } \\
\text { Total: }\end{array}$ & 47806 & 100 & 31749 & 1671 & 33420 & 11428 & 11428 & 100 & 77 \\
\hline
\end{tabular}

a Percentage basis is study area total

In Table 13.5, the average quantity of street litter available for each subsystem is determined as the product of the average street litter concentration (items/curb-km) and the curb length $(\mathrm{km})$, and represents the average reservoir of street litter items that are available for transport to the CSS via the catchbasins, expressed both as items and as a percentage of the total for the study area.

Street litter to CSS represents the relative quantity of litter that moves from the street into the CSS, and is calculated by applying the catch-basin retention rate (a function of how many catchbasins are equipped with litter-retaining gas traps) with the average quantity of litter available on the streets. (This quantity is expressed in terms of relative units rather than absolute items because the transfer of material from streets to catchbasins is considered to be proportional to the quantity of material on the streets; calculation of absolute items would require a mass balance involving the rates of litter deposition and litter removal due to both street sweeping and rainfall flushing to catchbasins).

The relative quantity of toilet litter in the CSS during wet weather is then estimated as $5 \%$ of the total (street litter plus toilet litter) floatables quantity. The capture of floatables at the regulators is then estimated by application of the capture of wet weather volume at the regulators (determined from hydraulic modeling), leaving the remainder as the quantity of floatables escaping capture at the regulators (i.e. floatables quantity in CSO). Since there are no end-of-pipe controls, the discharge of floatables to the receiving water is equal to the quan- 
tity of floatables in the CSO. The total floatables discharge is also expressed as a percentage of the total discharged from all subsystems in the study area.

The last column, overall floatables capture, expresses the overall capture of floatables (at catchbasins, at regulators, and at end-of-pipe controls) as a percentage of the total quantity of floatables that enter the catchbasins (as street litter) and the CSS directly (as toilet litter).

The results show that, for existing conditions, the overall combined sewer floatables capture rate for the study area is approximately $77 \%$. Among the combined sewer subsystems, the Rideau Canal Interceptor subsystem has the lowest overall capture efficiency (57\%), followed by Hemlock (79\%) and Booth Street Trunk (86\%). Overall floatables capture in the remaining subsystems exceeds $90 \%$.

Among the combined sewer subsystems, the Rideau Canal Interceptor subsystem represents the largest source of floatables in the study area. This is not surprising, given the fact that this subsystem contains the largest quantity of street litter. However, it is notable that, while the subsystem contains about $40 \%$ of the study area street litter, it represents about $74 \%$ of the combined sewer floatables discharged to the receiving waters. The reason that discharges from this subsystem are magnified relative to other subsystems is the low volume capture of wet weather flow at the Rideau Canal Interceptor regulatorat $28 \%$ (Table 13.4), this is by far the lowest in the study area and the primary cause of the low $57 \%$ overall floatables removal efficiency associated with the subsystem. The fact that such a large percentage of the combined sewer floatables discharged to the receiving waters originates from one subsystem may provide opportunities for focused, cost efficient control alternatives.

\subsection{Screening of Potential Floatables Control Alternatives}

This study compiled a list of over 70 potential floatables control alternatives and screened these alternatives to identify those likely to be feasible in Ottawa. Feasible alternatives were then classified according to general effectiveness and cost to identify the most cost effective options. Alternatives already being utilized in Ottawa were screened to determine whether expansion would be cost effective, since the analysis of existing conditions already included the existing level of control.

Table 13.6 presents the results of the screening analysis as a matrix of feasible alternatives, distributed in a matrix with the lowest cost, most effective controls located toward the upper left portion of the matrix, and the highest cost, least effective controls located in the lower right portion of the matrix. When an alternative is an expansion of a currently implemented action, that 
alternative is shown in bold font. Alternatives that have already been selected for implementation are shown in bold, italic font.

Table 13.6 Floatables control cost effectiveness matrix.

\begin{tabular}{|c|c|c|c|}
\hline & \multicolumn{3}{|c|}{$\begin{array}{l}\text { FLOATABLES-REDUCTION } \\
\text { EFFECTIVENESS }\end{array}$} \\
\hline & $\begin{array}{c}\text { HIGH } \\
(50-100 \%)\end{array}$ & $\begin{array}{l}\text { MEDIUM } \\
(10-50 \%) \\
\end{array}$ & $\begin{array}{l}\text { LOW } \\
(<10 \%)\end{array}$ \\
\hline $\begin{array}{l}\text { 5 } \\
\text { ठ } \\
3 \\
0\end{array}$ & $\begin{array}{c}\text { Expand Catchbasin Gas } \\
\text { Traps }(+) \\
\text { Real Time Control / } \\
\text { Expand Regulator Capacity }(+) \\
\text { Baffle Vaults }(+) \\
\text { Netting Systems }(+)\end{array}$ & $\begin{array}{c}\text { Implement SOP } \\
\text { Expand Waste Basket Servicing } \\
\text { Expand Public Waste Baskets } \\
\text { Expand Public Education(+) }\end{array}$ & $\begin{array}{l}\text { Expand Community Cleanups } \\
\text { Expand Litter/Trash-Related } \\
\text { Ordinances } \\
\text { Catchbasin Stenciling/Badging } \\
\text { Adopt-A-Street } \\
\text { Rain Barrels/Cisterns }\end{array}$ \\
\hline 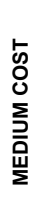 & $\begin{array}{c}\text { Expand Catchbasin Gas } \\
\text { Traps(-) } \\
\text { Real Time Control / } \\
\text { Expand Regulator Capacity(-) } \\
\text { Baffle Vaults(-) } \\
\text { Netting Systems(-) } \\
\text { Mechanical Screens(+) } \\
\text { Vortex Separation(+) }\end{array}$ & $\begin{array}{c}\text { Expand Public Education } \\
\text { Programs(-) } \\
\text { Expand Stormwater Storage } \\
\text { Facilities } \\
\text { Expand Stormwater Infiltration } \\
\text { Devices } \\
\text { Cleaning in Business Improvement } \\
\text { Areas }\end{array}$ & $\begin{array}{l}\text { Expand Water Conservation } \\
\text { Expand Recycling Program } \\
\text { Parking-Lot Stormwater Storage } \\
\text { Roof-Leader/Sump-Pump } \\
\text { Disconnect } \\
\text { Outfall Relocation }\end{array}$ \\
\hline 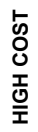 & $\begin{array}{l}\text { Mechanical Screens(-) } \\
\text { Vortex Separation(-) } \\
\text { Off-Line Storage } \\
\text { Increase Conveyance Capacity } \\
\text { Increase STP Capacity }\end{array}$ & Expand Street Sweeping & $\begin{array}{l}\text { Infiltration/Inflow Reduction } \\
\text { Expand Sewer Separation }\end{array}$ \\
\hline
\end{tabular}

Pursuant to cost effective control of CSO volumes, Ottawa has already developed and initiated implementation of a plan to utilize RTC to cost effectively reduce CSO frequency and discharge volumes. This RTC plan involves a variety of measures that function together according to an optimized operational plan to maximize use of available in system storage. These measures include upgrades to regulator capacity and functionality, upgrades to pumps and associated controls at the STP, a monitoring system, and a system optimization plan (SOP). Implementation of this RTC plan is anticipated to increase the volumetric capture of combined sewage overall, and particularly in the Rideau Canal Interceptor subsystem, where volume capture is significantly lower than other subsystems under existing conditions. In the Rideau Canal Interceptor subsystem, implementation of RTC is expected to increase wet weather volume capture to $85 \%$ from $28 \%$.

Installation of catchbasin gas traps is one of the most cost effective alternatives for floatables control. Furthermore, because Ottawa already has gas traps installed in roughly a third of study area catchbasins, this alternative represents 
an expansion of a proven technology that is already familiar in Ottawa, and one that is likely to be readily implementable. Other generally cost effective controls, such as screens, baffles, netting systems and in-basin booms, have issues involving siting and unusual excavation costs. As a result, the study retained RTC and installation of catchbasin gas traps for analysis of floatables control.

\subsection{Modeling Analysis of Selected Floatables Control Alternatives}

The floatables modeling analysis described above for existing conditions was applied for each of the selected control alternatives, both as separate controls and together. The impact of implementing RTC was analyzed by replacing the existing capture of combined sewage with the expected capture with RTC. The impact of installing gas traps in all combined sewer catchbasins was analyzed by replacing the existing percentage of gas traps with $100 \%$, effectively increasing the retention of floatables in catchbasins to $76 \%$ for the entire combined sewer area. The impact of both controls being in place at the same time was also analyzed. Figure 13.3 summarizes the study results with respect to the overall, study-area capture rate of combined sewer floatables. The two curves represent the reasonable range of results, depending upon the sensitivity of floatables capture at the regulators for each of the modeled scenarios.

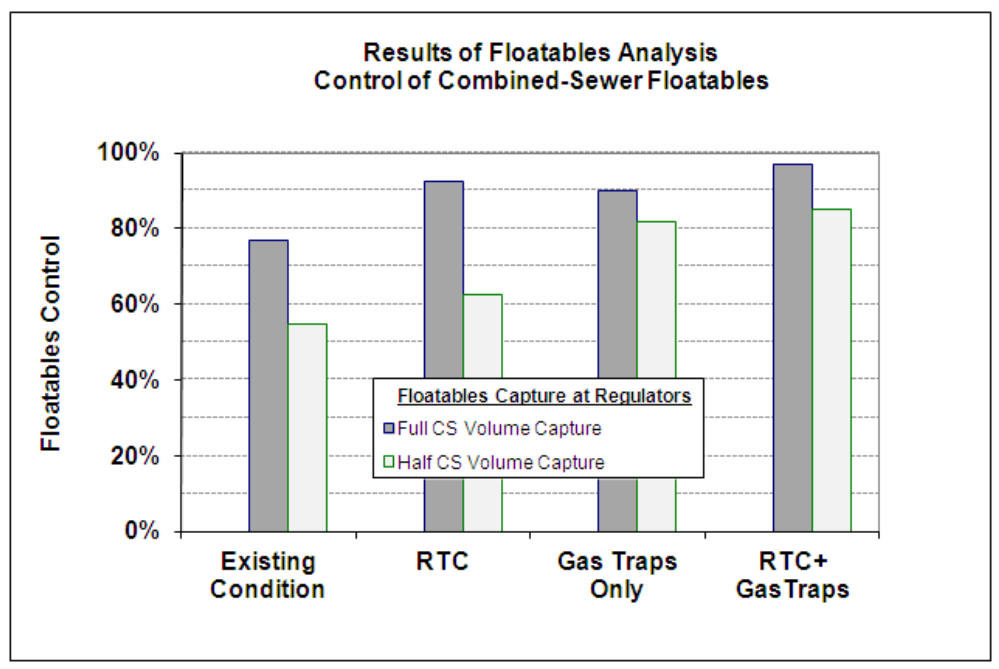

Figure 13.3 Overview of floatables capture results. 
As shown, the city's existing system already controls $55 \%$ to $77 \%$ of the floatables that enter the combined sewer system (including street litter entering catchbasins and toilet litter entering the combined sewers directly). With RTC, the overall combined sewer floatables capture rate will increase to between $62 \%$ and $92 \%$. If gas traps are installed without RTC, the overall combined sewer floatables capture rate would be $82 \%$ to $90 \%$. Assuming that gas traps and RTC are implemented together, the overall combined sewer floatables capture rate would be $85 \%$ to $97 \%$.

\subsection{Conclusions and Recommendations}

The City of Ottawa successfully performed a floatables study featuring field monitoring and desktop modeling analyses to assess current conditions, future conditions reflecting implementation of an already planned RTC system, and future conditions reflecting other floatables control alternatives. The study recommended installation of catchbasin gas traps within the study area as a cost effective alternative that, when combined with RTC, is expected to increase control of CSO floatables to between $85 \%$ and $97 \%$, compared to the existing control level of between $55 \%$ and $77 \%$. The study further recommended that the floatables monitoring program (begun to characterize conditions during the initial year of the study) be continued for a period of three years to track factors such as street litter levels, prevalence of catchbasin gas traps, volume capture of combined sewage at regulators, and floatables levels in and along the city's receiving waters.

\section{References}

Allison, R.A, T.A. Walker, F.H.S. Chiew, I.C. O’Neill, T.A. McMahon, 1998. "From Roads to Rivers: Gross Pollutant Removal From Urban Waterways." Published by the Cooperative Research Centre for Catchment Hydrology, Melbourne, Australia. May, 1998. ISBN 1876006323

CDM, 1996. "The Wethersfield Cove Floatables Control Management Plan.” Prepared by Camp, Dresser \& McKee, Inc. and HydroQual, Inc. for the Metropolitan District of Hartford, Connecticut, March, 1996.

HydroQual, Inc., 1993. "City Wide Floatables Study, Final Report, Sources, Fate and Control of Floatable Materials in New York Harbor." Prepared for the New York City Department of Environmental Protection, Bureau of Environmental Engineering, Division of Water Quality Improvement, December 1993

HydroQual, Inc., 1995. "City Wide Floatables Study, Floatables Pilot Program Final Report, Evaluation of Non-Structural Methods to Control Combined and Storm Sewer Floatable Materials." Prepared for the New York City Department of Environmental Protection, Bureau of Environmental Engineering, Division of Water Quality Improvement, December 1995. 
HydroQual Engineers \& Scientists, P.C., 2005. "City Wide Comprehensive CSO Floatables Plan, Modified Facilities Planning Report.” Prepared for the New York City Department of Environmental Protection, Bureau of Environmental Engineering, July 2005.

NYC, 2010. "The Scorecard Program: Overview."

http://www.nyc.gov/html/ops/html/scorecard/scorecard.shtml

Newman, Thomas L., Leo, W.M., Gaffoglio, R., 1999. "Characterization of Urban Source Floatables." Water Environment Federation, Collection Systems Wet Weather Control, May, 2000.

SAIC, 1987. "New Jersey Floatables Study: Possible Sources, Transport and Beach Survey Results." Prepared by Science Applications International Corporation for the New Jersey Department of Environmental Protection, under sponsorship of U.S. Environmental Protection Agency, Region II; November 1987. 